\title{
Front Matter: Volume 10220
}

, "Front Matter: Volume 10220," Proc. SPIE 10220, Dimensional Optical Metrology and Inspection for Practical Applications VI, 1022001 (16 June 2017); doi: 10.1117/12.2280894

SPIE Event: SPIE Commercial + Scientific Sensing and Imaging, 2017, Anaheim, SPIE. CA, United States 


\section{PROCEEDINGS OF SPIE}

\section{Dimensional Optical Metrology and Inspection for Practical Applications VI}

Kevin G. Harding

Song Zhang

Editors

13 April 2017

Anaheim, California, United States

Sponsored and Published by

SPIE 
The papers in this volume were part of the technical conference cited on the cover and title page. Papers were selected and subject to review by the editors and conference program committee. Some conference presentations may not be available for publication. Additional papers and presentation recordings may be available online in the SPIE Digital Library at SPIEDigitallibrary.org.

The papers reflect the work and thoughts of the authors and are published herein as submitted. The publisher is not responsible for the validity of the information or for any outcomes resulting from reliance thereon.

Please use the following format to cite material from these proceedings:

Author(s), "Title of Paper," in Dimensional Optical Metrology and Inspection for Practical Applications VI, edited by Kevin G. Harding, Song Zhang, Proceedings of SPIE Vol. 10220 (SPIE, Bellingham, WA, 2017) Seven-digit Article CID Number.

ISSN: 0277-786X

ISSN: 1996-756X (electronic)

ISBN: 9781510609419

ISBN: 9781510609426 (electronic)

Published by

SPIE

P.O. Box 10, Bellingham, Washington 98227-0010 USA

Telephone +1 3606763290 (Pacific Time) · Fax +1 3606471445

SPIE.org

Copyright (c) 2017, Society of Photo-Optical Instrumentation Engineers.

Copying of material in this book for internal or personal use, or for the internal or personal use of specific clients, beyond the fair use provisions granted by the U.S. Copyright Law is authorized by SPIE subject to payment of copying fees. The Transactional Reporting Service base fee for this volume is $\$ 18.00$ per article (or portion thereof), which should be paid directly to the Copyright Clearance Center (CCC), 222 Rosewood Drive, Danvers, MA 01923. Payment may also be made electronically through CCC Online at copyright.com. Other copying for republication, resale, advertising or promotion, or any form of systematic or multiple reproduction of any material in this book is prohibited except with permission in writing from the publisher. The CCC fee code is $0277-786 \mathrm{X} / 17 / \$ 18.00$.

Printed in the United States of America.

Publication of record for individual papers is online in the SPIE Digital Library.

\section{SPIE. DIGITAL \\ SPIEDigitalLibrary.org}

Paper Numbering: Proceedings of SPIE follow an e-First publication model. A unique citation identifier (CID) number is assigned to each article at the time of publication. Utilization of CIDs allows articles to be fully citable as soon as they are published online, and connects the same identifier to all online and print versions of the publication. SPIE uses a seven-digit CID article numbering system structured as follows:

- The first five digits correspond to the SPIE volume number.

- The last two digits indicate publication order within the volume using a Base 36 numbering system employing both numerals and letters. These two-number sets start with 00, 01, 02, 03, 04, 05, 06, 07, 08, 09, OA, OB ... 0Z, followed by 10-1Z, 20-2Z, etc. The CID Number appears on each page of the manuscript. 


\title{
Contents
}

\author{
$\checkmark$ Authors \\ vii Conference Committee
}

SESSION 1 METROLOGY AND 3D METHODS

1022003 3D shape measurement using image-matching-based techniques (Invited Paper) [10220-2]

1022004 High-speed 3D surface measurement with mechanical projector [10220-3]

1022005 High-speed, high-accuracy large range 3D measurement [10220-4]

1022006 Design and implementation of an electronic system to real-time capture and processing speckle interference patterns [10220-5]

\section{SESSION 2 METROLOGY ANALYSIS}

1022007 Wavelength dependency of optical 3D measurements at translucent objects using fringe pattern projection [10220-6]

1022008 Influence of the measurement object's reflective properties on the accuracy of array projection-based 3D sensors [10220-7]

1022009 Absolute phase unwrapping for dual-camera system without embedding statistical features [10220-8]

10220 OB Measuring optical phase digitally in coherent metrology systems [10220-10]

\section{SESSION 3 METROLOGY APPLICATIONS I}

10220 OE Optimized measurement of gaps [10220-13]

10220 OF Temporal speckle correlations for optical alignment [10220-14] 


\section{SESSION 4 METROLOGY APPLICATIONS II}

1022001 Three-dimensional metrology for printed electronics [10220-17]

$10220 \mathrm{JJ}$ Measurement of material thickness in the presence of a protective film [10220-18]

POSTER SESSION

10220 OP Fast 3D NIR systems for facial measurement and lip-reading [10220-23] 


\title{
Authors
}

Numbers in the index correspond to the last two digits of the seven-digit citation identifier (CID) article numbering system used in Proceedings of SPIE. The first five digits reflect the volume number. Base 36 numbering is employed for the last two digits and indicates the order of articles within the volume. Numbers start with 00, 01, 02, 03, 04, 05, 06, 07, 08, 09, 0A, OB...0Z, followed by 10-1Z, 20-2Z, etc.

\author{
Álvarez-Tamayo, R. I., 06 \\ An, Yatong, 05 \\ Barcelata-Pinzon, A., 06 \\ Brahm, Anika, OP \\ Breitbarth, Andreas, 07 \\ Bromberg, Vadim, 01 \\ Durán-Sánchez, M., 06 \\ Harding, Kevin, $\mathrm{OE}$, Ol, OJ \\ Heist, Stefan, 08, OP \\ Hyun, Jae-Sang, 04 \\ Jiang, Chufan, 09 \\ Juarez-Salazar, R., 06 \\ Kelly, Damien P., OB, OF \\ Kühmstedt, Peter, 08, OP \\ Meneses-Fabian, C., 06 \\ Moreno-Guzmán, J., 06 \\ Navarro-Ahuatl, M. A., 06 \\ Nguyen, Hieu, 03 \\ Notni, Gunther, 07, 08, OP \\ Ramamurthy, Rajesh, OE, OJ \\ Ramm, Roland, OP \\ Rangel-Romero, C., 06 \\ Rosenberger, Maik, 07 \\ Rulff, Christian, OP \\ Ryle, James, OB \\ Schurig, Florian, OF \\ Sheridan, John T., OB \\ Wang, Zhaoyang, 03 \\ Zhang, Chen, 07 \\ Zhang, Song, 04, 05, 09 \\ Zhao, Liang, OB
}


Proc. of SPIE Vol. $102201022001-6$

Downloaded From: https://www.spiedigitallibrary.org/conference-proceedings-of-spie on 26 Apr 2023 Terms of Use: https://www.spiedigitallibrary.org/terms-of-use 


\section{Conference Committee}

Symposium Chair

Majid Rabbani, Rochester Institute of Technology (United States)

Symposium Co-chair

Robert Fiete, Harris Corporation (United States)

Conference Chairs

Kevin G. Harding, GE Global Research (United States)

Song Zhang, Purdue University (United States)

Conference Co-chair

Edward W. Reutzel, Pennsylvania State University (United States)

Conference Program Committee

Harbans S. Dhadwal, Omnitek Partners, LLC (United States)

Motoharu Fujigaki, University of Fukui (Japan)

Khaled J. Habib, Kuwait Institute for Scientific Research (Kuwait)

Damien P. Kelly, Technische Universität Ilmenau (Germany)

Peter Kühmstedt, Fraunhofer-Institut für Angewandte Optik und Feinmechanik (Germany)

Rongguang Liang, College of Optical Sciences, The University of Arizona (United States)

Georges T. Nehmetallah, The Catholic University of America (United States)

Gunther Notni, Fraunhofer-Institut für Angewandte Optik und Feinmechanik (Germany)

Lei Tian, Boston University (United States)

Joseph D. Tobiason, Micro Encoder Inc. (United States)

Zhaoyang Wang, The Catholic University of America (United States)

Jiangtao Xi, University of Wollongong (Australia)

Session Chairs

1 Metrology and 3D Methods

Kevin G. Harding, GE Global Research (United States)

2 Metrology Analysis

Song Zhang, Purdue University (United States) 
3 Metrology Applications I

Song Zhang, Purdue University (United States)

4 Metrology Applications II

Damien P. Kelly, University College Dublin (Ireland) 